\title{
Mobility Trope: Travelling as a Signature of the Afropolitan Female Quest for Existential Subjectivity in Chika Unigwe's On Black Sisters' Street
}

\begin{abstract}
The mobility trope is a key aesthetic feature in Afropolitan fiction and it crystalizes as the act of travelling which has become an important subject-matter in postnationalist African fictions by women such as Chimamanda Adichie, Noviolet Bulawayo or Chika Unigwe as a way of intervention on the debate of the Afropolitan female quest for existential subjectivity in $21^{\text {st }}$ century African fiction. This is against the backdrop of negative essentialism and the exertions of patriarchy evident in the representation of African women's in $20^{\text {th }}$ century African fiction. Drawing from the foregoing, this paper interrogates Chika Unigwe's On Black Sisters' Street (Hence OBSS) to demonstrate how the writer deploys mobility trope which manifest as travelling as a signature of the Afropolitan female quest for existential subjectivity. I argue in this paper that, though existing studies on OBSS portray Efe, Sisi, Ama and Joyce as exported commodities in neoliberal sex market, their relocation however opens up a new vista to understanding their motivation and quest for new subjectivity, empowered fluid agency, individual autonomy and translation into Afropolitans. This is within Achille Mbembe's phenomenological criticism of Afropolitanism and a methology that is based on qualitative content analysis of the text-OBSS. On the long run, the identity which travelling confers on the female characters is fluid, as they represent an African being in a globalized world and a strong sense of cultural mobility.
\end{abstract}

KEYWORDS: travelling, signature, Afropolitan, existential, subjectivity, Chika Unigwe, agency

\section{Introduction}

The debate on female subjectivity remains largely, a very crucial topic today, in contemporary African feminist discourse as it informs to a large extent, the aesthetic imagination of the African woman in neoliberal/postcolonial/postmodern discourse and modern fiction. More so, it is a backdrop to Nwapa (2007), pertinent question on "how [...] African literary texts project women?" (p. 527). Immanent in such debate is the need to de- 
construct essentialist imagery which portrays the African woman as a canvass upon which institutional, socio-economic and cultural forces legislate and make inscription upon.

This is coming on the heels of the new turns in feminist imagination in modern African fiction. We need to note that the $20^{\text {th }}$ century colonial/postcolonial imagination of African women has been from a victimhood perceptive, static geographical confinement, powerlessness, and disempowered agency, but the new turn in 21st century imagination of the African woman imbue the African woman with a rhizomatic existence, a metropolitan agency, and an ability to subvert hierarchies of subjugation. The outcome is that contemporary imagination of African women are in terms of what Bratman (2007) calls "autonomy, self-governance and agential authority" (p. 4). Thus, for the fact that colonial or postcolonial imagination of African women essentialism fictionalises modern African women as an abstractions created by men according to Udumukwu (2015, p. 273), makes such imagination an aporia (Udumukwu, 2007, p. 19), a subtle manicheanism aggravated by the troubled genealogies of modern African states.

There are three models or strategies of female identity representation in Nigeria's postcolonial literature as underscored by Omotayo Oloruntoba-Oju \& Taiwo Oloruntoba-Oju (2013, p. 5-18) include: entrenchment, negotiation and challenge. Following a neo-liberal/postmodern tradition which basically seek to argue that individual's freedom depends on the existences of a free operational system, Omotayo Oloruntoba-Oju \& Taiwo Oloruntoba-Oju (2013) challenge the essentialized identity stencilled on the modern African women by a rigid culture which is phallocentric. And in his analysis of OBSS, Umezurike (2015), this is also one of the underlying conjectures Umezurike seeks to make that a phallocentric culture makes it difficult for African women to reconstitute their agency (p. 152) at several fronts whether it is economic, cultural, institutional, and political. It also impedes African women's right to self-definition through an elaborate regime of rules, social codes and taboos.

Examples of the foregoing include: Aleks mother's admonition to Alek in $O B S S$ "Do not play football, Alek. It's not lady like. Do not play 'awet, it's for men only. Do not sit with your legs spread like that, Alek, it's not ladylike. Do not. Do not. Do not. Do not" (Unigwe, 2010, p. 185); or the characterisation of Li in Zainab Akali's Stillborn, Firdaus in Nawal El Saadawi's Woman at Point Zero, Iyese or Emilia in Okey Ndibe's Arrows of Rain, Nita in Ifeanyi Ajaegbo's Sarah House, Mara in Amma Darko's Beyond the Horizon, Aissatou and Ramatoulaye in Mariama Ba's So Long a Letter, and 
Nnuego in Buchi Emecheta's Joys of Motherhood. These characters are iconographies of colonised bodies and they speak of colonial metaphors of subjugation.

By a way of response to such essentialized subjectivity, Afropolitan feminism have emerged as an aesthetic transition in Afro-feminist discourse. It seeks to counter negative aesthetic imagination of African women through its anti-essentialist writing which challenges subservient metaphorisation of women by institutions (family, church, governance, education) as powerless, passive, static agents, geographically confined by the kind of social roles inscribed upon the body of Africa women as produced, distributed and consumed in various artistic media.

Afropolitan feminist writers are alert to those essentialism and ontological stereotypes in colonial/postcolonial fictions such as Mr Johnson by Joyce Cary, Jagua Nana's Daughter by Cyprian Ekwensi, Things Fall Apart by Chinua Achebe, The Last Duty Isidore Ekpewho, The Concubine Elechi Amadi, Petals of Blood, but they choose to subvert such imaginations in their creation of Afropolitan female characters whose motivations are driven by desires for existential subjectivity and self-empowerment through what Ede (2018) calls "professional excellence". We see this in the character Ifemelu, created by Chimamanda Adichie's in Americanah, and Buchi Emecheta's creationAdah-in Second Class Citizen, Ama and Joyce in Unigwe's On Black Sisters' Street, or Darling in We Need New Names by NoViolet Bulawayo. They are good examples of Afropolitan female characterisations in modern fictions who through hard work, subvert hierarchies of female subjugation and powerlessness in African and in the diaspora by their professional excellence. The characters are existentially driven in their quest for subjectivity signalled by their choices and action by any means necessary which reflect the ideological traces of neoliberal concerns with breaking free.

The Afropolitan feminist writer's characterisation presages the writer's commitment to Afropolitan feminist consciousness raising. A common strategic motif embedded in such writing is the creation of characters who are nomadic, travels or relocates outside Africa or leave the rural Africa to reside in Africa's metropole by their own volition. Such relocation into another space which for Sisi, Efe, Ama and Joyce is Belgium, offers the female characters opportunities to take charge of their lives and become existential subjects through their freedom to make choices against "the exertions of patriarchy" (Egya, 2018, p. 75).

We see the "exertions of patriarchy" demonstrated in the experiences of the character Ama and her mother in OBSS. They had to endure great 
physical and psychological humiliation in the hands of Brother Cyril who regulates their lives. Another example is evident in the consent given to Titus by his wife who is very much aware of Titus' sexual activities with young females. Titus' wife is passive at the reification of her own sex and gender by her husband. She could live with it, because:

From the day she married Titus and caught him looking at her chief bridesmaid with a glint in his eye, she had known that he had a roving eye. As long as women swayed their hips at him, he would go to them, a drooling dog in heat. It was not his fault; it was just the way he was created. She could live with it. He could have his women. Have their children, even. She had no problem with that. What she had a problem with, though, was the women turning up with their children and expecting him to take care of them (Unigwe, 2010, p. 71, boldface emphasis are mine).

The foregoing portrays Titus' wife as an inappropriate model or representation of the modern African women who seek a life that is self-regulated. For one would begin to wonder the logic which informed her acceptance of the assumption that men like Titus were created that way. The expression "It was not his fault; it was just the way he was created" reeks of a justified Hegelism, tantamount to living in a denial of existential fact. Titus' wife replies which is an explanation to justify Titus' lecherous lifestyle places her on a spot for interrogation. She exhibits traits of a "passive agency".

The idea of passive agency deployed here draw from transformational generative grammar when a kernel sentence inflects to assume a derived sentence. Passive agency is similar to the thematic role of elements in a sentence structure grammar where the object of a sentence through sentence transformational movement relocates and occupies the subject position but is incapable of real actions. While such object occupies a position meant for a subject, its actions are false and non-existing, because the object is a mere sufferer of an action, hence lacks the capacity to initiate real action. Thus, whatever action a passive agent may appear to initiate is an illusion. Titus' wife represents that passive agent. While Efe visits Titus to present his baby to him, Titus is mute, calm and appears dumb, instead, his wife, takes the floor, and makes utterances, and actions which should have been performed by Titus. But whatever Titus' wife uttered reveals to a large extent how deeply entrenched she is in her role as a passive agent. This kind of agency is a product of an acculturation due to prolong exposure to phallocentric culture which betrays the Afropolitan feminist ideal, since Afropolitanism as an anti-essentialist frame, rejects Hegelian totality (p. 29). 
The consequence of prolong exertion of patriarchy on women is the voluntary conscription of women in as cyborgs who justify their own slavery and prevent their own sex manumission. Other subtle form "the exertion of patriarchy" in postcolonial feminist novels manifests are in terms of men and society making legislation-similar to a command economic system - on the issue of marriage as we see in the dilemma of Polycarp who wants to marry Alek but his parents discouraged it (Unigwe, 2010, p. 225), which also played out in travails of the characters Aissatuo and Ramatoulaye (Chukwuma, 2003, p. 44), and the regulation of body, subjectivity and voice as we see in Firdaus a character in Woman at Point Zero by Nawal El Saadawi (Udumukwu, 2007, p. 60). The exertion of patriarchy therefore describes African women as patients, sufferers, being without proper self-individuation, at best, they are reified beings whose actions are limited to just complain and indifference.

\section{Postcolonial Conditions in Lagos and Sudan: When the State Becomes the Eye of Medusa}

The postcolonial conditions of Nigeria and Sudan as imagined in OBSS speak of unemployment, joblessness, declining economic activities and corruption for Lagos, and a society ravaged by civil conflict as we see in Sudan. The situation in Lagos greatly define the amount and quality of life options available to Efe, Chisom and Ama. On the other hand, the civil crisis in Sudan speaks of a traumatised nation manifesting ailment of colonial disruption. This nation is metaphorised in the character Alek (Joyce) whose body which was raped speaks of plunder of Sudan by warring citizens. The memory of her childhood experience of rape, death and carnage hover around her like a phantom. The Nigerian and Sudanese states renegade on their duty to their citizens. For instead of an assured wellness and the safeguard of the lives of individuals through the securing of their liberty, economic well-being, social, cultural, political expectations, the states assumed the instrument which negates its own role. The city of Lagos and the country Sudan become the eye of the mythic medusa, which turn her victims into dead stones. What this implies is that the institutions and systems in place reify the characters desires and agency, for as individuals, they look up to the state but instead of support, they become calcified, paused, and lifeless towards their goals and dreams. 
Contemporary Lagos imagined in OBSS represents the state in this regard. Its binary of urban centres and ghettos serve as one of the narrative settings in OBSS. It offers precarious conditions of existence which adversely affected Chisom's (Sisi) desires for agency. Chisom desires to work to earn good money, but the job is not forth coming as she is trapped in a manicheanism of hope and despair. Two years after leaving a university, she still roams the city of Lagos mainly unemployed even after writing several application letters to several banks without getting a reply. To her chagrin, even her less intelligent classmate gets a job because they are connected (Unigwe, 2010, p. 22).

And not being able to cope with such reality, Chisom, like a liminal, is tied up in a dilemma, a desires for escape as she could not stand another year in Lagos (State) (Unigwe, 2010, p. 30). This is the same challenge which confronts Efe. Efe desires a new meaning and purpose in life beyond that which the city of Lagos offered her. Sisi (Chisom) and Efe serve as iconographies of Africa's contemporary women in modern fiction who seek a new type of subjectivity, economic, social and corporeal freedom. They seek to break free from the eye of Medusa-the state. These desire for freedom crystalizes in their capacity to make their own choices and finally, their travel to Belgium, not minding the many months of chattel slavery as commercial sex workers which await them, as we see in the works of Kamalu \& Ejezie (2016); Otu (2016); Chukwudi-Ofoedu (2017); Courtois (2019). An expression which represents the characters obstinate desire for freedom is the statement made by Chisom "I must escape" (Unigwe, 2010, p. 30).

Urama and Nwachukwu (2017, p. 124) has read the travelling of Sisi, Efe and Ama as a type of escape (p. 124),while this is logical, there is also a need to see their action as a symbolic act, of breaking free, a quest for new subjectivity and agency away from the dilemma Lagos offered. In a bid to free themselves from the dilemma of existence in Lagos they had to make difficult choices, choices with obvious consequences they could not escape from. Meanwhile we need to note that even if they had refused to go to Belgium that, in itself is a choice. The choice before them is thus between two degrees of evil, the greater evil is what appeared as an assured poverty and a life of probably misery in Lagos without any hope of life getting better. A limbo like existence. The lesser evil is also a life of great risk outside Lagos-in Belgium - which allows them to get reward for their labour and send money to their home country and siblings.

The actions of Sisi, Efe, Ama translate them into existential subjects, neoliberal beings, who choose their own path in life, and are willing to 
accept the risk that comes with these choices and their readiness to follow any commitment it brings, to the end. Sisi, Efe, Ama did not make their choices in abstraction but in consideration of the fact that a new geography such as Belgium, offered more options for them, than is readily available in Lagos. Their gaze on Lagos has yield nothing but pain, penury and differed dreams. This decision is not necessarily an afro-pessimism, but a sensibility which enables one identify ones critically assess reality in the light of experiences and circumstances before taking up subjectivity as an identity. This type of subjectivity or agency transcend the traditional Hegelian notion of agency associated with women experience, which Reinares (2019) argues, can actually constitute a huge problem than solving any of the African female problem (p. 57). It is a type of problematized female agency, an agency in a dilemma, what Ligaga (2019) calls an ambiguous agency (p. 82).

\section{Travelling/Nomadism as a Signature of Female Action in OBSS}

Characters like Sisi (Chisom), Efe, Ama and Joyce in OBSS, represent women agitation for new subjectivity through demonstrated through travelling. Travelling a type of nomadism is galvanised beyond mere movement from one point to another to assume a semiotic act, a signature of the characters quest for existential subjectivity. The lexical term signature in the noun phrase a female signature of action has its origin in structural linguistics of Roman Jakobson, importantly, is drawn from the sense in which Udumukwu (2007) deployed it, that is, as a conventional sign capable of symbolic representations (p. 29-30).

Thus, travelling constitutes a conventional signature for the characters like Sisi, Efe, Joyce and Ama because of what it symbolises for them. It symbolises the power of such female characters to sub-vert, re-imagine and re-make themselves with new semantic inscriptions other than what postcolonial Nigeria and Sudan imposed on them. This allows for a form of agency, subjectivity denied them in their previous geography.

Traveling as a signature also speaks of the resistance put forth by the characters to the institutionalized poverty in Lagos. It is a resistance to the socio-economic, political and cultural challenges they faced in Lagos as African women. These conditions made takes their gaze to Europe which seemed like an Eldorado (Ligaga, 2019, p. 82). For while Lagos reifies 
them, Europe lures them as a place for new subjectivity. Subjectivity as used here is in line with the sense Sartre used it, as "simply our proper being, that is, the obligation on us to have to be our being, and not simply passively to be" (p. 44). Most importantly, their travelling underwrites their motivation, desires and hope. It becomes a chance for them to break free from the grip of Lagos, while offering them a new phenomenology of experience in other geographies, or what (Smethurst, 2008) calls "imaginative geographies" (p. 1).

Lastly, travelling as a signature of action reveals Unigwe's handling of the poetics of postcolonial mobility or movement as an aesthetic design, to underscore the fact that beyond the notion of relocation that comes to mind when the word travelling is mentioned in the novel, travelling also carries within it, specific authorial ideologies and journey metaphors of desire and hope for a better life elsewhere. This is important as Ashcroft (2015) has shown that "Almost all journeys [travelling] are begun in hope. While they may not begin with the expectation of arriving at utopia, the impetus of travel is essentially utopian because it is driven by hopeful expectation in one form or another" (p. 249).

The experiences and causality behind the desire to travel by each of Unigwe's character is captured in an anti-linear pattern of plot representation with an interconnected twist of events which bring the character to a centre in Belgium. The meeting of the characters in Belgium gives focalisation to each character's life when they hold the narrative floor to talk about themselves. This also allows the reader to become familiar with the choices each had to make, the options available to each character and how all of those point to their individual quest for existential subjectivity. Thus, for a reader to fully grasp the meaning behind the movements of the female characters from one geographical area to another in the novel, the pertinent question should be, what does the female characters hope to gain by relocating elsewhere? Not only that, another important question is, what ideology is masked and unveiled in the text in the travelling and movements of the characters.

\section{Afropolitan Feminism, Travelling and New Subjectivity in OBSS}

Afropolitan feminism is an anti-essentialist, deconstructive discourse model. It is different from other sub-typologies of African feminism which 
Nnolim (2009) highlighted, such as womanism, accommodationist, reactionary/middle of the roaders, and gynandrists (p. 137-138). The word Afropolitan before feminist is an adjective.

The adjective 'Afropolitan' is a shorthand for 'African and cosmopolitan', cosmopolitanism, being a macrocosm of transculturation, borderlessness, bi- or multi-ethnicity, bilingualism, near-nomadic and rhizomatic existence, urbanity and expansive worldliness, which the substantive, Afropolitanism, contemplates philosophically and critically (Ede, 2018, p. 37).

Afropolitan feminism is a neoliberal and postmodern afro-feminist theorising that have emerged in the twenty first century. If we recalled that the need to provide nouveau afro-feminist theorising began to emerge after Ogundipe-Leslie (1994) called for a new theorising of feminism by African women in other to enable African women talk about themselves within their own lenses (p. 208). Afropolitan feminism fills in this gap as it as one of the:

[...] determining factors that will have an impact on women's lives beyond 2015 and into the 2015-2035 generation, and which will contribute to the development of a new kind of feminism, more compatible with the requirements of the development of our continent and more capable of integrating the principles of equity and social justice are the main command variables of the current evolution of women in our countries, which are the strongest variables, are not really driving forces and are difficult to change (Ndiaye, 2014, p. 67).

Afropolitan feminism has gradually gain ground in art, media and literary and philosophical discourse. But we must not forget that it emerged from Afropolitanism, a concept in cultural phenomenology which overturns the predominant euro-western reading of Africa (Mbembé \& Nuttall, 2004, p. 352). The concept of Afropolitanism has continued to gain popularity, this is amidst the controversy which trailed its pros and cons when Taiye Selasi virialized it in 2005 (Morales, 2017, p. 223).

At the core of the Afropolitan aesthetics is the subject of travelling, relocation or poetics of mobility of the African from Africa to other cultural spaces but such would not have been possible without a recourse to the neoliberal sensibilities at work in African economies. Afropolitanism also takes postcolonial discourse to a new level and vistas of understanding due to its laisser-faire out lock. This is noteworthy because travelling adumbrates and re-enforces a semiotic pattern in Afropolitan 
discourses and novels. It has assumed a sign system, a poetic of mobility for the Afropolitan feminist signature of action. We see this in Ghana Must Go, Travellers, Homegoing, foreign gods, inc., Second Class Citizen, We Need New Names, Americanah among others. In those texts, travelling or relocation is a common motif. And beyond that, travelling points to an ideologically motivated action with which Afropolitan writers instigate Afropolitan consciousness.

What we mean by travelling as an ideologically motivated act, is that it serves as a type of semiotic system, an anti-language of resistance against patriarchal expectations from women and the institutionalised conditions of unemployment and poverty in Lagos which makes it difficult for Chisom (Sisi), Ama and Efe to live the type of life they want to live, a life of meaning. As an ideologically motivated action, relocation is a performatory action which signals a change of social status, and the emergence of a new form of subjectivity which they hope to enjoy in Antwerp.

The figural implication of travelling is its metalinguistic transposition of meaning from a denotative sense to a metaphor of that which triggers a status change through movement from Lagos to Belgium. We see the changes in the translations of Chisom, Efe, Ama when they arrived Belgium. Even after Ama and Joyce came back to Lagos to establish some enterprises after they had paid for their freedom, they arrived in Lagos, transformed (by experiences in other climes) just like Ifemelu the protagonist in Americanah. They became self-individuated being who have become translated into Afropolitan by their experiences, knowledge of the world and other cultures in their journey and travels.

The new identity conferred on them by their travels marked their break away from the normalisation which comes with the conditions they find in Lagos which the likes of Chisom's mother, Mama Eko, and Titus' wife have come to accept. It is a postmodernist break with tradition and norms. The four characters-Sisi, Efe, Ama and Joyce-are therefore symbolic representation of post-modern African women who are dissatisfied with patriarchal orthodoxy with it essentialized framing of women as a weak, passive, and a subservient other. These postmodern African women are willing to break free from such framing by any means necessary. They also fit into the frame of deviant modern bohemian African women. They are deviant in that they chose not to conform to the desires dictates of the society in Lagos, or the exertion of patriarchy. Importantly, they are free from ethnocentric or racial biases in the solving of their predicaments themselves. 
Of all the benefits of travelling to Efe, Sisi, Joyce and Ama, the new sense of female consciousness, self-awareness and individuation stand out. They are availed with the opportunity to encounter other cultures and Africans like them. We see this in the party Efe held in honour of late Iya Ijebu, a woman she took as her granny while she was in Lagos. In this party:

There would be lots of Ghanaians; those people were everywhere. Nigerians, of course, went without saying. A sprinkling of East Africans-Kenyans who ate samosas and had no traditional clothes and complained about the pepper in Nigerian food, not really African. The three Ugandan women she knew who stumbled over their words, brackening black and renthening long. And the only Zimbabwean she knew, a woman who shuffled when she danced (Unigwe, 2010, p. 9).

The foregoing excerpt apart from the fact that it speaks of the attendants as guest also alerts a reader to the naming of the nationality of the guest. This opens another vistas of meaning which we can draw from the excerpt. By naming each guest by their nationality, Unigwe calls attention to the distinctive nationness of the various linguistic grouping that make up Africa as a continent. A continent with humans of distinct geographical spaces against the generalisation of such distinct people as if they are without a distinct identity, but just Africans. This is one of the ways colonialism universalises the African identity. The foregoing presupposes that Africa is not a country as has been projected in colonial discourse of Africa, but a continent with unique linguistic forms and people with different nationalities, identity and should be seen and addressed as such. While Unigwe did not bother to tell her readers about the lives of these women who attended the party hosted by Efe, it is obvious that Unigwe confers them with a sense of nationness in spite of the fact that such women are in the diaspora and they share a sense of collective effervescence as Afropolitan females with diasporic identities.

\section{Travelling as a Signature of the Afropolitan Feminist Quest for Existential Subjectivity}

Sisi, Efe, Ama, and Joyce, who had, had to leave Lagos for Antwerp due to the limited options Lagos offered them (p. 114) through the help Dele are encumbered by the realities of life. These women are from different social groups but got to meet in Belgium by virtue of their relocation. 
Their relocation also translated them into Afropolitans as they encountered new cultures and geographies. It sheds light on how a change in geographical location redefines the rights, privileges, options available to an individual. We see this in the statement made by Sisi (Chisom) when she came to Belgium "I'm very lucky to be here (Antwerp in Belgium), living my dream. If I'd stayed back in Lagos, God knows where I'd have ended up" (Unigwe, 2010, p. 15).

The words, "here" and "dreams" serve a socio-semiotic function as a deixis for location and with a paradigmatic substitute "there" which points to Lagos, a troubling memory Sisi would not like to dredge up (Unigwe, 2010, p. 15). What Antwerp offered Sisi is a new life which smiled at her (2010, p. 2). This new life translates as new subjectivity, akin to the word agency which is drawn from the word agent and also speaks of a self, "the active subject marked by particular qualities in virtue of which a distinct, persistent identity is had" (Oshana, 2010, p. 15). The four characters gain a new life or agency by their ability to make their own decisions which altered the course or trajectory of their lives on their own freewill after considering their available options.

Each of the characters are not without a motivation in their quest for a new life or existential subjectivity. For Sisi, it was the desire to control the options life offered her and her family in Lagos, since Lagos did not offer her much. Chisom (Sisi) is a university graduate of Finance and Business Administration of Unilag, and one would expect that her life would have better promises to offer in the city of Lagos, but that was not possible. She lived with her parents (Godwin and his wife) in a Flat at Ogba (p. 17). All her teenage and young adult life in Lagos was lived to fulfil the desires and expectations of her parents and they weighed heavily on her young shoulders. She was always mindful of her father's hope for her (Unigwe, 2010, p. 20) and her father who never had a formal schooling due to circumstances, unconsciously projected his dreams into Chisom.

The declining economy of Lagos as reflected in OBSS made it difficult for Chisom to fulfil her father's desires and goal for her. This made Chisom conclude that, "Lagos was a city of death and she was escaping it" (p. 98). So much so that, when she got the offer (from Dele) she did not turn it down" (Unigwe, 2010, p. 23). She went ahead like someone "heading into the light of her future", for "she was ready to set forth bravely into her future." (Unigwe, 2010, p. 48). One sentence which summarises her tenacity is "I must escape" (p. 30). 
Her arrival in Belgium demonstrates her relocation. She saw her new life stretching out like a multi-coloured vista before her eyes. Belgium thrilled Sisi such that she knew that she would make it here (p. 98). In Sisi's travel, and quest is a desire to get away from the haunting memory of pain, of a life not lived or expressed in the city of Lagos and which the name Chisom reminds her of. She had to change her name from Chisom to Sisi, for to her, her Nigerian name was dead. Snuffed out. A nobody, swallowed up by the night (p. 102).

Ironically, Chisom in Igbo means my Chi goes with me. Chi here means a life force, a personal kindred spirit in Igbo mythology Achebe has mentioned succinctly in Things Fall Apart, Arrow of God. But in this case, it appears nothing seems to work for her in Lagos with that name Chisom, thus, the need for a name change even as she embraces her new job, and identity in Antwerp, "the place to be when your dreams died" (p. 105). Sisi imagines the quality she could bring to the life of her father for:

With the amount of money, she imagined she would earn, there would be no limit to her purchasing power. She would even be able to buy her father a chieftaincy title in their village. Buy him some respect and a posture that belonged to a man his age (Unigwe, 2010, p. 172-173).

On the other hand, Efe's quest for a new subjectivity is motivated by the need to provide a better life for her son Lucky Ikponwosa. Efe, like Chisom is also from a home ravaged by unemployment and poverty, a consequence of failed institution. Her family lacks a proper house and bathroom which makes Efe fantasize over a proper house with a tub and two taps which she saw in magazines (Unigwe, 2010, p. 55). Efe also lacked parental care which made her discovered sex at the age of sixteen (Unigwe, 2010 , p. 49). Her father, after the death of their mother resort to drinking while a bulk of the responsibility of taking care of the children-three siblings-fell upon the young shoulders of Efe (Unigwe, 2010, p. 58). This is because the money her father gave her every month was barely enough for food" (Unigwe, 2010, p. 58).

The only way Efe could make some money to take care of her siblings was to accept the sexual advances made to her by Titus which for Efe "Dat one na small price to pay" (Unigwe, 2010, p. 58). Contained in the expression "Dat one na small price to pay", speaks deeply of an uttered opinion of Efe, about life and existence. One of the meaning such expressions presupposes is that she (Efe) has been paying prices much more than that, even 
if it was not in form of having sex with an older man. It is in the context of Efe's situation that one can fully grasp the full weight of Efe's statement and its existential import-that she is willing to do anything necessary. All Efe desired was a good life (p. 55), but Lagos offered her little opportunity, coupled with the fact that her life got complicated when she gets pregnant for Titus. This comes with a certain amount of social stigma as people look at her as dirt (p. 65) particularly from her fellow women.

Worthy of note is the conversation between Efe and her younger sibling Rita "where Rita states that if the baby is a boy his father (Titus) will definitely want him (p. 65) since men wanted sons no matter how many they had, sons were trophies they had collected to carry on family names. This goes to a large extent to reveal the masculinist sensibility which guide gender perception. And importantly, the sociocultural dent associated with a young girl who gets pregnant outside wedlock as we see the statement made by Efe, "Which kin' man go marry woman wey don get pikin already?, because she would never be a perfect wife". (Unigwe, 2010, p. 75-76).

The only way Efe could gain back the meaning of her life is to travel to Belgium. She gets the blessings of Rita her younger sister in form of a hug and her request for a Mercedes (p. 85). And in Europe (Belgium) she quickly assimilates with other cultures (p.104). One of the reasons women like Sisi and Efe can be called Afropolitan females is because of their travels to other geographies such as Antwerp. A place Madam acknowledges changes a person (p. 177), not necessarily because of the nature of their job as sex workers, but because of the cultural tapestry of Belgium, the freedom that comes with it, and the individuality Belgium offers. The existential subjectivity the characters seek would be one which will require all four to make tougher decisions such as not asking much questions and doing as they were told until they are able to pay back the money which Dele invested on them to get to Belgium, as madam got to let Sisi to know.

My dear Sisi, it's not your place to ask questions here. You just do as you're told and you'll have an easy ride. I talk, you listen. You understand? Three days ago I gave Joyce the same instruction. She did not ask me questions. She just listened and did as she was told. I expect the same of you. Silence and total obedience. That is the rule of the house. Be seen, not heard. Capeesh (Unigwe, 2010, p. 120).

Ama, one of the four, grew up in Enugu with a troubled childhood. She was not allowed to have many friends by an overprotective, dotting, religious fanatic and rapist: brother Cyril, the man she assumed was her fa- 
ther (Unigwe, 2010, p. 123). Brother Cyril, an Assistant Pastor literarily locked up Ama, in a cage of rules and regulations on what to listen to, what to drink, the type of magazine to read (Unigwe, 2010, p. 129), such that Ama's only friend was "a pink wall" (p. 123). The wall was the only friend Amah could complain to.

Over the next days the walls heard how he ignored her when she said that he was hurting her inside. They heard of how she tried to push him away when he lay on top of her, but he was a mountain, and she did not have the strength in her to move a mountain. She told of the grunting and the sticky whiteness like pap that gushed out of him. "It's warm and yucky," she complained to her walls. "I'll never eat pap again!" The walls could sketch her stories. They could tell how she wished she could melt into the bed. Become one with it. She would hold her body stiff, muscles tense, as if that would make her wish come true. When she did this, her father would demand, "What's the Fifth Commandment?" "Honor thy father and thy mother," she would reply, her voice muffled by the collar of her nightgown in her mouth. And then she would relax her muscles, let him in, and imagine that she was flying high above the room. Sometimes she saw herself on the ceiling, looking down at a man who looked like her father and a girl who looked like her. When the pain made this difficult, she bit on her lower lip until it became numb (Unigwe, 2010, p. 132).

The wall, apart from being Ama's confidante also speaks of a wall of obstacles before women and how talking to the wall was not an effective solution since no action to either pull down the wall or walk away from it was engaged. It speaks of the caged subjectivity of Ama and her mother. They were mere objects influences by culture and social expectations.

Ama was expected by Cyril to "follow in her mother's footsteps and become a model wife for a good Christian man someday (Unigwe, 2010, p. 131). But Ama never wanted to live like "her mother [who] allowed herself to be subjugated" (p. 146). The word silence which describes Ama's mother resonates with being subservient, passive and docile in order to fit into the essentialized subjective framing of women particularly from the Igbo society. And we see this silence crystalize when Ama tells her mother that Brother Cyril raped her, and how her mother reaction in terms of silence towards Cyril. And as the violation continue, Ama a girl of 8 years old at that time, told the wall her closest friend that she wants to go abroad (Unigwe, 2010, p. 134). What abroad implies for Ama was that she wants to get free. But Lagos was still not enough for Ama. Though it offered a better life than Ama had in Enugu, "its predictability, its circular motion that 
took her from the small flat to the tiny Empire and back to the flat, nibbled at her soul, which still yearned to see the world (Unigwe, 2010, p. 159). And Ama wanted better and more from life.

What connects Sisi, Efe and Ama is this same quest for a better life. For Ama, even as she makes up her mind to travel to Belgium, knowing fully well that she is going there to become a commercial sex worker, "her thoughts already on a new life far from here, earning her own money so that she could build her business empire. And once she was a big woman people would respect her, even brother Cyril. It was this dream that spurred her on in Antwerp" (p. 169). Thus, even against the wishes of Mama Eko, Ama remained obstinate. She was willing to do whatever it takes to get a slice of the beauties of life, in Belgium. What makes Ama's travel less a dilemma like Efe and Sisi is evident in the fact that she never had an existence in Lagos what she calls "life behind" (Unigwe, 2010, p. 177).

Joyce, a Sudanese, whose real name is Alek is one of the four girls. She is the daughter of Nyok, and she seldom thinks about her past, "preferring to concentrate on the future, on what her life will be once she leaves Madam's establishment" (Unigwe, 2010, p. 180). Not until Efe harassed her with questions to open up about herself did she finally opened up. But the death of Sisi that made her had some time to think about herself and life generally. And her memory was not a pleasant one as what stayed tucked within Joyce is the memory of a fifteen-year-old girl who witnessed the gruesome murder of her father, mother and brother in the hands of militia men who repeatedly raped her. (Unigwe, 2010, p. 192-193).

Polycarp was the opportunistic soldier who helped Joyce leave the refugee camp, and he took her to Nigeria. Polycarp offered her another view to live through the travels he made with her to Lagos Nigeria. But Polycarp was not willing to stand for her and beside her, it appeared Polycarp was a friend. In fact, it appears Polycarp betrayed her and sold her into chattel slavery as a commercial sex worker since he is a good friend of Dele. It was Polycarp who offered her to Dele, who changed her name to Joyce. The loss of family, the rape and troubled life as a refugee, the betrayal from Polycarp, her experiences in Belgium, made her resolved from now on, she would never let her happiness depend on another's. She would never let anyone hurt her. She would play life's game, but she was determined to win (Unigwe, 2010, p. 231). Importantly, Joyce was able to buy back her freedom and live the life she wants.

Of the four women, only Sisi met a sad end. While Efe pursued a life as a pimp living her life the way she wants, Joyce would go back to Nigeria 
with enough capital to set up a school in Yaba. She would employ twenty-two teachers, mainly young women, and regularly make concessions for bright pupils who could not afford the school fees. She would call it Sisi's International Primary and Secondary School, after the friend she would never forget. Ama, ironically, would be the one to open a boutique. She would make Mama Eko its manager. Mama Eko would tell her she always knew Ama would make it. They would never talk about Ama's years in Europe (p. 279).

\section{Conclusion}

We have argued in this paper that travelling constitutes a poetics of mobility with which Unigwe projects her Afropolitan feminist consciousness and neoliberal rationalities. In addition, OBSS challenges the negative essentialism of African women in fiction through the character of Efe, Sisi, Ama and Alek via their quest for subjectivity which crystalizes as travelling. While this essay does not seek to make a final note on the debate on subjectivity as imagined in Africa's feminist discourse, it projects travelling as a way of subverting the perverted imagination of African women in modern fiction. A salient point in this essay is that beyond the notion of African women as exported commodities in neoliberal sex market in Europe, their travelling also translated them into Afropolitans while exposing them to new forms of agency and neoliberal cultures. In addition, Unigwe's handling of characterization through her creation of characters with troubled childhood in Africa who later travelled to Antwerp in Belgium before returning to Africa is a type of Afropolitan poetics of mobility and encountering new spaces. The transformation which the characters undergone speaks of the capacity of travelling to map new identity, a type this essay sees as fluid, Rhizomatic, emancipatory and existential subjectivity for the African women. And we believe that the thoughts shared in this essay we spark other new ways of re-reading Unigwe's OBSS.

\section{REFERENCES}

ASHCROFT, B. (2015) Travel and Utopia. In: Kuehn, J. \& Smethurst, P. (eds.) New Directions in Travel Writing Studies. London: Palgrave Macmillan.

BRATMAN, M. E. (2007) Structures of agency: Essays. New York: Oxford University Press. 
CHUKWUDI-OFOEDU, A. E. (2017) The domination and sexual objectification of women in Chika Unigwe's On Black Sisters' Street. Journal of humanities and social policies. 3 (1). Pp. 1-9.

CHUKWUMA, H. (2003) Accents in the African novel. Nairobi: Pearls Publishers.

COURTOIS, C. (2019) The travelling bodies of African prostitutes in the transnational space in Chris Abani's "Becoming Abigail" (2006) and Chika Unigwe's "On Black Sisters' Street" (2009). In: Pellicer-Ortín, S. \& Tofantšuk, J. (eds.) Women on the Move: Body, Memory and Femininity in Present-Day Transnational Diasporic Writing. New York-London: Routledge. Pp. 25-45.

EDE, A. (2018) Afropolitan Genealogies. African Diaspora. 11 (1-2). Pp. 35-52.

EGYA, S. E. (2018) The Gendered and Commodified Female Body in Contemporary Nigerian Fiction. Africa Development. 43 (1). Pp. 75-89.

KAMALU, I. \& EJEZIE, B. O. (2016) Ideational representation of prostitution and social meaning in Chika Unigwe's On Black Sisters' Street. Inkanyiso: Journal of Humanities and Social Sciences. 8 (2). Pp. 108-116.

LIGAGA, D. (2019) Ambiguous agency in the vulnerable trafficked body: Reading Sanusi's Eyo and Unigwe's On Black Sisters' Street. Tydskrif vir Letterkunde. 56 (1). Pp. 74-88.

MBEMBÉ, J. A. \& NUTTALL, S. (2004) Writing the world from an African metropolis. Public Culture. 16 (3). Pp. 347-372.

MORALES, D. (2017) An Afropolitan 2017 update. Journal of the African Literature Association. 11 (2). Pp. 223-237.

NDIAYE, N. (2014) The role of women as Afropolitanists, a new brand of feminism for today's Africa? OSIWA. [Online] Available from: http://www.osiwa.org/afropolitanism/the-role-of-women-as-afropolitanists/.

NNOLIM, C. (2009) "Contemporary Nigerian Fiction" Issues in African literature. Yenagoa: Treasure Resources Communication Limited.

NWAPA, F. (2007) Women and creative writing in Africa. In: Olaniyan, T. \& Quason, A. (eds.) African literature. An anthology of criticism and theory. Wiley-Blackwell. Pp. 526-532.

OGUNDIPE-LESLIE, M. (1994) Re-Creating Ourselves: African Women and Critical Transformations. Africa World Press.

OLORUNTOBA-OJU, O. \& OLORUNTOBA-OJU, T. (2013) Models in the construction of female identity in Nigerian postcolonial literature. Tydskrif vir Letterkunde. 50 (2). Pp. 1-14.

OSHANA, M. (2010) The importance of how we see ourselves self-identity and responsible agency. Lanham: Lexington Books.

OTU, O. O. (2016) Prostitution: The Economics Of Sex And Power Dynamics In El Saadawi's Woman At Point Zero, Adimora-Ezeigbo's trafficked And Unigwe's On Black Sisters' Street. World Journal of English Language. 6 (4).

REINARES, L. B. (2019) The Pedagogies of Sex Trafficking Postcolonial Fiction: Consent, Agency, and Neoliberalism in Chika Unigwe's On Black Sisters' Street. Canadian Review of Comparative Literature/Revue Canadienne de Littérature Comparée. 46. (1). Pp. 56-76.

SARTRE, J. P. (2016) What is subjectivity? Verso Books. 
SMETHURST, P. (2008) Introduction. In: Kuehn, J. \& Smethurst, P. (eds.) Travel Writing, Form, and Empire: The Poetics and Politics of Mobility. New York: Routledge. Pp. 1-18.

UDUMUKWU, O. (2007) Signature of women the dialectics of action in African women's writing. Owerri: Onii Publishing House.

UDUMUKWU, O. (2015) Literary Theory and Criticism: An Introduction. Port Harcourt: Charles-Martins Higher Education and Consulting Company.

UMEZURIKE, U. P. (2015) Resistance in Amma Darko's Beyond the horizon and Chika Unigwe's On Black Sisters' Street. AFRREV LALIGENS: An International Journal of Language, Literature and Gender Studies. 4 (2). Pp. 152-163.

UNIGWE, C. (2010) On Black Sisters' Street. London: Vintage.

URAMA, E. N. \& NWACHUKWU, C. O. (2017) Human trafficking: Commercial sexual exploitation and forced domestic labour in African literature. Journal of Language and Cultural Education. 5 (2). Pp. 123-137. 